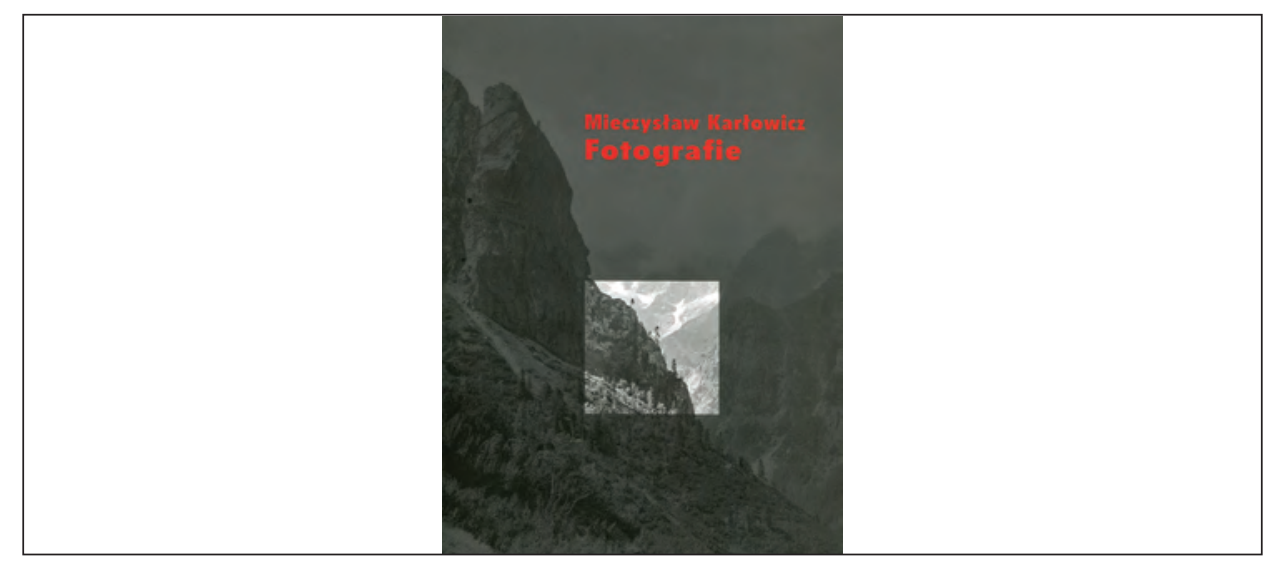

\title{
Poematy fotograficzne Mieczysława Karłowicza
}

https://doi.org/10.19195/2084-4107.13.30

[rec.:] Mieczysław Karłowicz, Fotografie, oprac. i red. Zbigniew Ładygin, Oficyna Wydawnicza „Wierchy”, Centralny Ośrodek Turystyki Górskiej PTTK, Kraków 2019, ss. 334.

\section{Photographicpoems by Mieczysław Karłowicz}

Słowa-klucze: Mieczysław Karłowicz, Tatry, Zakopane, fotografia, album

Keywords: Mieczysław Karłowicz, Tatras, Zakopane, photography, album

W 2019 roku minęło 110 lat od śmierci Mieczysława Karłowicza. Kompozytor zginął, przysypany lawiną, w trakcie górskiej wędrówki 8 lutego 1909 roku. Okrągła rocznica tego tragicznego wydarzenia, poważnej straty dla polskiej kultury muzycznej, sprowokowała Centralny Ośrodek Turystyki Górskiej PTTK do publikacji okazałego albumu Mieczysława Karłowicza, Fotografie, w opracowaniu Zbigniewa Ładygina. Jest to trzecia w ostatnich latach próba zaprezentowania postaci Karłowicza jako taternika, miłośnika gór, narciarza oraz przede wszystkim fotografa. Książka została wyróżniona Dyplomem Muzeum Sportu i Turystyki w Warszawie na 28. Ogólnopolskim Przeglądzie Książki Krajoznawczej i Turystycznej, który odbył się w dniach 14-16 lutego 2020 roku w Poznaniu. Stanowiła ponadto temat jednego z panelu podczas Zakopiańskiego Festiwalu Literackiego; 10 sierpnia 2019 roku w dyskusji o albumie, zatytułowanej $W$ kręgu Karłowicza, wzięły udział cztery osoby bezpośrednio związane z towarzyszącym jej procederem wydawniczym oraz odpowiedzialne za merytoryczny kształt publikacji. 
O książce rozmawiali Jerzy Kapłon (wydawca książki), Anna Król (historyczka sztuki), Zbigniew Ładygin (redaktor albumu) oraz Maciej Pinkwart (historyk, znawca twórczości Karłowicza).

Omawiana książka stanowi najambitniejszą i najpełniejszą dotąd próbę zaprezentowania fotografii okolic Zakopanego wykonanych przez Mieczysława Karłowicza. Jest to album w dużej mierze syntetyzujący dotychczasowe publikacje, które zawierały zdjęcia Karłowicza. Książka wydana jest bardzo starannie, w dużym formacie $(30 \times 22 \mathrm{~cm})$, na papierze Arctic Volume $130 \mathrm{~g}$, dzięki czemu wydrukowano fotografie w bardzo dobrej jakości.

Do współpracy przy tworzeniu publikacji redaktor a zarazem autor dwóch zamieszczonych w nim tekstów, Zbigniew Ładygin, zaprosił wybitnych znawców życia i twórczości kompozytora, przedstawicieli różnych dziedzin naukowych: Macieja Pinkwarta, literaturoznawców Jacka Kolbuszewskiego oraz Małgorzatę Łoboz, muzykologa Władysława Malinowskiego oraz historyczkę sztuki Annę Król. Lista autorów sugeruje, że bardzo istotnym czynnikiem selekcji materiału do książki był wykładnik interdyscyplinarny. Jest to niezwykła zaleta tego albumu informacje dotyczące Karłowicza prezentowane są z różnych punktów widzenia, każdy tekst przedstawia inny pomysł interpretacyjny, a jednocześnie w trakcie lektury można odnieść mocne wrażenie wewnętrznej koherencji dzieła jako całości. Teksty wzajemnie się uzupełniają i dopełniają, tworząc — przy uwzględnieniu i zachowaniu wszelkich proporcji — syntetyczny obraz życia oraz działalności artystycznej Karłowicza.

Układ książki jest bardzo prosty i czytelny. Około dwu trzecich jej objętości zajmują fotografie, którym towarzyszy zwięzła opisowa specyfikacja. Reszta, a więc jedna trzecia, to teksty naukowe, podzielone na dwa działy. Pierwszy z nich, zatytułowany Człowiek osobny, został zaplanowany i ułożony w oparciu o kryterium biograficzne. Część druga, najistotniejsza z punktu widzenia prezentacji materiału fotograficznego, zatytułowana jest zwyczajnie: Fotografie. Reszta książki, blisko 200 stron, prezentuje najpełniejszy zebrany jak dotąd zestaw fotografii Karłowicza. Pod względem edytorskim publikacja została wykonana bardzo starannie. Samo somatyczne obcowanie $\mathrm{z}$ albumem sprawia nader satysfakcjonującą przyjemność. Dodatkowo, by ułatwić czytelnikowi poruszanie się po książce, sporządzono dwa obszerne skorowidze: osobowy oraz geograficzny.

Kompozytor doczekał się już wcześniejszych licznych opracowań o charakterze monograficznym, wśród których dominuje, co zrozumiałe, perspektywa muzykologiczna. W obliczu takiego stanu rzeczy omawiany album to tym bardziej cenna propozycja wydawnicza. Książka udowadnia, że Mieczysław Karłowicz był nie tylko wielkim symfonikiem, lecz przede wszystkim człowiekiem wielu talentów - jest wszak Karłowicz także fotografem i pisarzem. Co jednak istotne w kontekście wydanej książki — wybitnym taternikiem oraz jednym z pionierów nowego sposobu ideologizacji estetycznej pejzaży tatrzańskich.

Album rozpoczyna się od intrygującego wstępu Jerzego Kapłona, który w skrócie ujawnia motywacje towarzyszące powstaniu książki. Bardzo podobną 
funkcję pełni kończący publikację tekst Zbigniewa Ładygina, w którym autor rekapituluje najistotniejsze informacje dotyczące albumu. Te dwa teksty tworzą swoistą ramę całości.

Artykuł Macieja Pinkwarta rozpoczyna właściwą, merytoryczną, część książki. Szkic ma charakter wprowadzenia biograficznego, którego celem jest uporządkowanie podstawowych informacji o życiu kompozytora. Pinkwart bardzo szczegółowo prezentuje dokumenty świadczące o pobycie Karłowicza w poszczególnych obszarach górskich. Historyk kolejno ukazuje różne etapy budowania subtelnej relacji między kompozytorem a Tatrami i Zakopanem. Zachowując chronologiczny układ tekstu, opowiada historię życia Karłowicza - od zawiązania relacji z górami w 1899 roku, przez kolejne przystanki w latach kolejnych, aż do 1907 roku, kiedy Karłowicz osiada w Zakopanem na stałe. Autor pokazuje jednocześnie, w jaki sposób otoczenie kompozytora kształtowało jego późniejszy stosunek do tego miejsca. Tezą zasadniczą tekstu Pinkwarta jest przekonanie, że to pierwszy wyjazd Karłowicza w góry był w istocie kluczowym zalążkiem późniejszego przestrzennego i pejzażowego afektu. Dobry warsztat i precyzja faktograficzna badacza umożliwia prześledzenie szlaków wędrówek kompozytora, miejsc, które odwiedzał, oraz przede wszystkim - tych, które fotografował.

Szkic Jacka Kolbuszewskiego został zorientowany wokół charakterystyki poszczególnych typów działalności Karłowicza, na co wskazuje sam tytuł: Mieczysław Karlowicz - kompozytor, pisarz, taternik i fotograf. Kolbuszewski na początku zwraca uwagę na powszechne przekonanie, że Karłowicz „w każdym z wymienionych obszarów reprezentował wybitne kompetencje i legitymizował się nieprzypadkowymi osiągnięciami” (s. 29). Według uczonego owe „działalności" pozostają z sobą w relacji, choć najczęściej stanowią rodzaj instytucjonalnej mistyfikacji. Największą zaletą artykułu jest tendencja autora do weryfikacji obiegowych przekonań dotyczących osoby Karłowicza. Badacz wskazuje, że nawet muzyka Karłowicza ma jedynie luźny związek z Tatrami — jest on raczej wykreowany niż rzeczywisty. Najważniejszym wątkiem tekstu są analizy i interpretacje zależności literackich obecnych w życiu i muzyce Karłowicza (s. 37). Kolbuszewski zastanawia się nad poziomem artystycznym tekstów programowych kompozytora, nad znaczeniem literackich inspiracji. Autor zadaje także zasadne pytanie o relację między muzyką Karłowicza a tekstami poetyckimi, którymi kompozytor się inspirował lub które twórczo wykorzystywał.

Kolejny szkic, autorstwa Małgorzaty Łoboz, reprezentuje zarówno muzykologiczne, jak i literaturoznawcze metody badawcze. Tekst podzielono na trzy części. W pierwszej z nich badaczka wyjaśnia, jakie z punktu widzenia historyka muzyki i literatury klasyfikacyjne problemy sprawia muzyka Karłowicza. W drugiej części analizie i interpretacji zostają poddane „momenty literackie” w muzyce instrumentalnej kompozytora. W trzeciej zaś badaczka, w optyce komparatystycznej, interpretuje, w jaki sposób pieśni Karłowicza korespondują z wykorzystanymi przez niego tekstami poetyckimi. Autorka szkicu bardzo precyzyjnie wskazuje różnice między historycznoliteracką a historycznomuzyczną parcelacją tak zwanych 
epok artystycznych. Zwraca uwagę na przynależność Karłowicza do przynajmniej trzech z nich: Młodej Polski, neoromantyzmu oraz postromantyzmu. Przestrzega jednak przed ich utożsamianiem. Ostatecznie wypada autorce stwierdzić, że „indywidualizm Karłowicza wymyka się jakimkolwiek zaszeregowaniom” (s. 54). W części poświęconej literackim inspiracjom Łoboz wyraźnie odnotowuje, że ładunek sugestywny w muzyce Karłowicza umożliwia rozpoznanie jego struktur ideowych. Nie jest to bowiem element o funkcji ilustracyjnej. Słynne programy utworów badaczka określa mianem raczej lirycznych komentarzy (s. 50). Nie był wszak Karłowicz zwolennikiem muzyki semantycznej. W ostatniej części szkicu autorka konfrontuje ostentacyjną niechęć Karłowicza do liryki pieśniowej z jego maniakalną potrzebą czerpania natchnienia z literatury. Łoboz udowadnia, że kompozytor na poziomie melodyki oraz ogólnego zamysłu organizacyjnego kompozycji całkiem przytomnie nawiązuje do estetyki i ideologii romantycznej oraz młodopolskiej, zwłaszcza do wierszy tanatologicznych Kazimierza Tetmajera, twórczości Juliusza Słowackiego i Zygmunta Krasińskiego (s. 61).

Autor kolejnego artykułu, Władysław Malinowski, zastanawia się nad semantyką słów: „taternik” oraz „turysta”. W czasach Karłowicza były one używane wymiennie: „Taternik znaczyło tyle co miłośnik Tatr, powracający do nich turysta" (s. 65). Malinowski bardzo ciekawie pokazuje, w jaki sposób doszło do przemieszczenia semantycznego w wyrazie „taternik”. Za jedną z przyczyn uznał działalność taternicką Karłowicza. Kompozytor zapoczątkował charakterystyczny sposób eksploracji przestrzeni górskiej — przez wędrówkę oraz osobiste doświadczanie. Autor tekstu uważa, że właśnie z tego powodu już wówczas kompozytora można było określić mianem taternika we współczesnym znaczeniu tego słowa. Drugi tekst Malinowskiego to drobiazgowe opracowanie, w formie przejrzystej tabeli, wszystkich znanych taterniczych tras wędrówek Karłowicza. Owo zestawienie kończy część dotyczącą życia kompozytora.

Kolejne trzy krótkie artykuły dotyczą kwestii warsztatowych. Autorzy prezentują z jednej strony uwarunkowania mentalne kompozytora, które pozwoliły mu rozwinąć talent $\mathrm{w}$ kierunku fotografii, $\mathrm{z}$ drugiej zaś - uwarunkowania materialne, a więc wykorzystywany przez Karłowicza sprzęt fotograficzny.

Anna Król wyznacza trzy hipotetyczne determinanty rozwoju wrażliwości kompozytora, które przypuszczalnie uplastyczniły jego fotograficzną wyobraźnię. Wymienia, po pierwsze, amatorskie rysunki kompozytora; po drugie, bezpośredni kontakt z malarstwem europejskim oraz polskim; po trzecie, fascynację pejzażowym górskim malarstwem japońskim, tak modnym w okresie Młodej Polski. Według badaczki zdjęcia Karłowicza do dziś mają znaczne walory artystyczne, a sam kompozytor wciąż inspiruje, pozostając indywidualnością „do odkrycia”.

Zbigniew Ładygin z kolei skupia uwagę czytelnika na technicznych aspektach aktywności fotograficznej Karłowicza. W tekście bardzo drobiazgowo przedstawione zostały różnice między różnymi typami aparatów. Autor mówi ponadto o sposobie użycia konkretnych typów papieru fotograficznego i o zmianach, jakie w tej materii zachodziły w ciągu lat. Podkreśla, że Karłowicz był w tych tech- 
nicznych nowinkach doskonale zorientowany. Ładygin pisze: „Karłowicz wymieniał wiedzę z innymi fotografującymi taternikami, chętnie dzieląc się swoimi doświadczeniami” (s. 92). Metodą działania był więc eksperyment, metoda prób i błędów. Jak zaznacza autor, zdjęcia wykonane przez kompozytora bardzo szybko znalazły poklask, jako że bardzo często rozsyłał je on do znajomych. Atrakcyjnym elementem tekstu Ładygina są zdjęcia oryginalnych aparatów Karłowicza, które się zachowały i należą dziś do zbiorów Muzeum Tatrzańskiego. Autor przedstawia losy poszczególnych aparatów używanych przez kompozytora, precyzuje ich specyfikację oraz możliwości. Jest to właściwie krótko opowiedziana historia życia z punktu widzenia aparatów fotograficznych.

Drugi tekst Ładygina jest poniekąd kontynuacją wątków podjętych wcześniej. Jakkolwiek przede wszystkim pełni funkcję komentarza do katalogu zdjęć kompozytora, które zebrano w omawianym albumie. Autor podaje charakterystykę poszczególnych fotografii, wskazuje na cechy znaczące, typ wykorzystanego papieru, sposoby utrwalania zdjęć na tymże papierze itp. Na sam koniec informuje o proweniencji materiału zdjęciowego wykorzystanego w albumie, podsumowując swoje rozważania w taki oto sposób: „wykaz nie rości sobie pretensji do kompletności. Zdjęcia w zasadzie ułożone są chronologicznie, ale kolejność ich wykonania w większości przypadków jest hipotetyczna" (s. 110).

Największym walorem omawianego albumu jest przekrojowość faktograficzna oraz merytoryczna i metodologiczna wielowymiarowość. Książka adresowana jest do szerokiego kręgu odbiorców, nie tylko naukowców. Można z niej czerpać zarówno estetyczną, jak i intelektualną uciechę. To lektura niemal obowiązkowa dla wszystkich miłośników Tatr i Podhala.

Łukasz Piaskowski

ORCID: 0000-0002-3528-4301

Uniwersytet Wrocławski lukasz.piaskowski@uwr.edu.pl 